\begin{tabular}{l|l|l||c|c|}
$\begin{array}{l}\text { Journal of } \\
\text { Endocrinology }\end{array}$ & $\begin{array}{l}\text { T Minamizaki, Y Konishi } \\
\text { et al. }\end{array}$ & $\begin{array}{l}\text { sKL causes hypomineralization } \\
\text { in Kllkl mice }\end{array}$ & $\mathbf{2 3 7 : 3}$ & $\mathbf{2 8 5 - 3 0 0}$ \\
\hline
\end{tabular}

RESEARCH

\title{
Soluble Klotho causes hypomineralization in Klotho-deficient mice
}

\author{
Tomoko Minamizaki1,*, Yukiko Konishi1,2,*, Kaoru Sakurai1,2, Hirotaka Yoshioka', Jane E Aubin³, Katsuyuki Kozai² \\ and Yuji Yoshiko'
}

1Department of Calcified Tissue Biology, School of Dentistry, Hiroshima University Graduate School of Biomedical \& Health Sciences, Hiroshima, Japan 2Department of Pediatric Dentistry, School of Dentistry, Hiroshima University Graduate School of Biomedical \& Health Sciences, Hiroshima, Japan ${ }^{3}$ Department of Molecular Genetics, University of Toronto, 1 King's College Circle, Toronto, Canada

Correspondence should be addressed to Y Yoshiko: yyuji@hiroshima-u.ac.jp

*(T Minamizaki and Y Konishi contributed equally to this work)

\section{Abstract}

The type I transmembrane protein $\alpha$ Klotho (Klotho) serves as a coreceptor for the
Key Words
- FGF23
- Klotho
- Phex
- $k l / k l$ mice

phosphaturic hormone fibroblast growth factor 23 (FGF23) in kidney, while a truncated

form of Klotho (soluble Klotho, sKL) is thought to exhibit multiple activities, including

acting as a hormone, but whose mode(s) of action in different organ systems remains to

be fully elucidated. FGF23 is expressed primarily in osteoblasts/osteocytes and aberrantly

high levels in the circulation acting via signaling through an FGF receptor (FGFR)-Klotho coreceptor complex cause renal phosphate wasting and osteomalacia. We assessed the effects of exogenously added sKL on osteoblasts and bone using Klotho-deficient ( $k / / k l)$ mice and cell and organ cultures. sKL induced FGF23 signaling in bone and exacerbated the hypomineralization without exacerbating the hyperphosphatemia, hypercalcemia and hypervitaminosis $D$ in $k l / k l$ mice. The same effects were seen in rodent bone models in vitro, in which we also detected formation of a sKL complex with FGF23-FGFR and decreased Phex (gene responsible for X-linked hypophosphatemic rickets (XLH)/ osteomalacia) expression. Further, sKL-FGF23-dependent hypomineralization in vitro was rescued by soluble PHEX. These data suggest that exogenously added $S K L$ directly participates in FGF23 signaling in bone and that PHEX is a downstream effector of the sKL-FGF23-FGFR axis in bone.

\section{Introduction}

$\alpha$ Klotho (Klotho) is a type I transmembrane protein with a large extracellular domain, a single-pass membranespanning segment, and a short intracellular carboxyl terminus without any phosphorylation sites. Klotho hypomorphic $(k l / k l)$ mice display various anomalies resembling a human senescence-related phenotype, including skin and muscle atrophy, vascular calcification and premature death (Kuro-O et al. 1997). In humans, a homozygous missense mutation (H193R) in KLOTHO is involved in severe tumoral calcinosis with dural and carotid artery calcifications (Ichikawa et al. 2007). KLOTHO gene polymorphisms (G395A in the promoter region and C1818T in exon 4) have also been associated with bone mineral density and multiple pathophysiologies in humans (Kawano et al. 2002, Shimoyama et al. 2009).

Klotho is highly expressed in kidneys and forms a complex with and converts canonical fibroblast growth factor receptors (FGFRs), in particular FGFR1, into a 
specific receptor for fibroblast growth factor 23 (FGF23), a phosphaturic hormone (ADHR Consortium 2000, Kurosu et al. 2006, Urakawa et al. 2006). It is therefore perhaps not surprising that loss of function of Klotho shares many common features with loss of function of FGF23 in mice, including increased serum levels of phosphate (Yoshida et al. 2002, Shimada et al. 2004b). FGF23, secreted primarily by osteoblasts and osteocytes (Riminucci et al. 2003, Yoshiko et al. 2007b), circulates in blood and acts together with membrane Klotho in renal tubules to suppress phosphate reabsorption and vitamin $\mathrm{D}_{3}$ activation (Larsson et al. 2004, Shimada et al. 2004a,b). Consistent with this, $k l / k l$ mice have extremely high levels of serum FGF23, and exhibit hyperphosphatemia, hypervitaminosis D and hypophosphatemic disorders (Segawa et al. 2007).

The widespread effects of Klotho deficiency on tissues/organs not expressing Klotho, such as seen in $\mathrm{kl} / \mathrm{kl}$ mice and conditions of Klotho haploinsufficiency in humans have suggested that Klotho functions through a circulating and, as yet, undefined, hormonal factor(s) (Kuro-O et al. 1997, Kawaguchi et al. 1999, Kawano et al. 2002, Shimoyama et al. 2009). Three Klotho protein types have been identified: a full-length transmembrane Klotho, a truncated soluble Klotho (sKL) and a secreted Klotho (Kuro-O et al. 1997, Matsumura et al. 1998, Wang \& Sun 2009, Xu \& Sun 2015). All types have been detected in humans and mice, but only the transmembrane and soluble Klotho proteins have been detected in rats (Matsumura et al. 1998, Wang \& Sun 2009). sKL arising from cleavage (shedding) of membrane Klotho by the metalloproteinase (ADAM) family members ADAM10 and ADAM17 (Chen et al. 2007) and a secreted Klotho by alternative splicing of Klotho are thought to be released into the circulation (Matsumura et al. 1998, Wang \& Sun 2009, Xu \& Sun 2015), but the function of sKL and secreted Klotho are not clear. Exact concentrations of serum sKL also remain uncertain, in part due to different forms of sKL and secreted Klotho and differences measured with different immunoassays, but levels of less than a few hundred nanograms per milliliter are seen in mice and humans (Kurosu et al. 2005, Pedersen et al. 2013). Treatment with sKL or transgenic overexpression of sKL extends mouse lifespan with multiple effects on insulin/insulin-like growth factor-I, TGF- $\beta$ and Wnt signaling (Kurosu et al. 2005, Liu et al. 2007, Chen et al. 2013), interaction with vascular endothelial growth factor receptor (VEGF)-2 and endothelial transient receptor potential canonical $\mathrm{Ca}^{2+}$ channels to regulate $\mathrm{Ca}^{2+}$ influx in aorta (Kusaba et al. 2010) and hydrolyzation of the glycosylated transient receptor potential ion channel TRPV5 in kidney (Chang et al. 2005, Wolf et al. 2014).

Previously, we demonstrated hypomineralization in osteoblast cultures overexpressing FGF23 (Wang et al. 2008). sKL has also been shown to interact with FGF23 (Kawai et al. 2013) and decrease chondrocyte proliferation via FGFR3 but increase proliferation while inhibiting differentiation-mineralization via FGFR1 in the MC3T3-E1 osteoblastic cell model (Shalhoub et al. 2011, Kawai et al. 2013). To further assess whether sKL contributes to FGF23 actions in bone and to eliminate confounding effects of membrane-associated Klotho, we used $\mathrm{kl} / \mathrm{kl}$ mice supplemented with and without sKL. We found that sKL promotes FGF23 signaling in $\mathrm{kl} / \mathrm{kl}$ bone and downregulates Phex, which contributes, at least in part, to sKL-FGF23-induced inhibition of bone mineralization.

\section{Materials and methods}

\section{Animals}

Klotho-mutant mice (kl/+; CREA Japan, Tokyo, Japan), C57BL/6J mice and timed-pregnant Wistar rats (Charles River Laboratories Japan) use and procedures were approved by the Institutional Animal Care and Use Committee at Hiroshima University (Approval \#A09-36). Genotyping of $\mathrm{kl} / \mathrm{kl}$ mice and wild-type (WT) littermates was performed as described previously (Brownstein et al. 2010).

Male C57BL/6J mice (age, 4 weeks) were treated with 1 1,25 -dihydroxyvitamin D3 (1,25 D; $6 \mu \mathrm{g} / \mathrm{kg}$ in ethanol:polyethylene glycol at 1:4 (vol/vol); Enzo Life Sciences, Farmingdale, NY, USA) subcutaneously once per day for 2 day, followed $24 \mathrm{~h}$ later by a single intravenous injection of sKL $(10 \mu \mathrm{g} / \mathrm{kg}$ in PBS) or vehicle (PBS) alone (Hines et al. 2004, Kawai et al. 2013). Sera, kidneys and bones were harvested $2 \mathrm{~h}$ after the sKL injection. Male $k l / k l$ and age-matched WT mice were treated with a subcutaneous sKL (or vehicle) injection $(10 \mu \mathrm{g} / \mathrm{kg}$; R\&D Systems) in $0.5 \%$ atelocollagen as carrier in PBS (Koken, Tokyo, Japan) into the dorsum every second day from postnatal day 10 (P10) to P22 (group $k l / k l+s K L$ ). Calcein $(10 \mathrm{mg} / \mathrm{kg}$ in $2 \%$ sodium bicarbonate) was injected intraperitoneally twice, at P14 and P20. All samples were collected at P22. 


\section{Cell and organ cultures}

The reagents used (final concentrations given in parentheses) were 1,25D (1-10nM), FGF23 and sKL (500 ng/mL each, unless otherwise specified; R\&D Systems) and MAPK inhibitors (for ERK, U0126; for Jun N-terminal kinase (JNK), dicumarol and for p38MAPK, SB203580; $10 \mu \mathrm{M}$ each). All other chemicals, unless otherwise specified, were purchased from Sigma-Aldrich. These reagents were dissolved as appropriate in ethanol, PBS or DMSO and maintained at -20 or $-80^{\circ} \mathrm{C}$ until use. Heparin $(1 \mu \mathrm{g} / \mathrm{mL})$ was included along with FGF23 when cells were maintained under serum-deprived conditions (see below).

We isolated calvarial cells from 21-day-old fetal rats or newborn $\mathrm{kl} / \mathrm{kl}$ and WT mice as described previously (Wang et al. 2008, Minamizaki et al. 2009). Cells were cultured in $\alpha$-MEM containing 10\% fetal bovine serum (FBS; HyClone; GE Healthcare Life Sciences) and $50 \mu \mathrm{g} / \mathrm{mL}$ ascorbic acid (osteogenic medium). Unless otherwise stated, cells adapted to serum-deprived conditions $(0.1 \%$ FBS in $\alpha M E M)$ for $24 \mathrm{~h}$ were used for mineralization studies; to induce matrix mineralization, cells were treated with $2 \mathrm{mM} \beta$-glycerophosphate for the last $24 \mathrm{~h}$ of culture and stained for ALP/von Kossa, followed by quantification using ImageJ (Bellows et al. 1986). We have previously reported the temporal expression profiles of osteoblast markers during differentiation and mineralization in rat calvarial (RC) cell cultures (Minamizaki et al. 2009).

RC cells transfected with human FGF23 recombinant adenoviruses (Adv-hFGF23) or adenoviruses expressing $\beta$-galactosidase (Adv- $\beta$ gal; BD Biosciences, San Jose, CA, USA) were obtained as described elsewhere (Wang et al. 2008).

For organ culture, two fragments (approximately $1.5 \times 3 \mathrm{~mm}$ ) randomly selected from parietal bones of WT or $\mathrm{kl} / \mathrm{kl}$ mice were placed on a cell culture insert in a well (BD Biosciences) in BGJb medium supplemented with $0.1 \%$ bovine serum albumin and recombinant human BMP-2 (50ng/mL; PeproTech, Rocky Hill, NJ, USA) for $24 \mathrm{~h}$, followed by fresh medium with or without sKL.

\section{FGF23, 1,25D, phosphate and calcium concentrations}

We measured FGF23 concentrations in sera, conditioned media and/or lysates of kidneys and bones using an FGF23 ELISA kit (intact FGF23, Kainos, Tokyo, Japan). Serum 1,25D and phosphate/calcium concentrations were quantified using a radioimmunoassay (TFB, Tokyo, Japan) and calorimetric determination kits (Wako Pure Chemical), respectively. Protein concentrations were determined using the BCA protein assay (Thermo Fisher Scientific).

\section{Western blotting}

Lysates or eluates from immunomagnetic separation were subjected to SDS-PAGE and blotted onto polyvinylidene difluoride membranes, which were incubated with primary antibodies (polyclonal antibodies against FGF23, phosphorylated and non-phosphorylated ERK1/2; 1:1000; Santa Cruz) and then HRP-conjugated secondary antibodies (1:2000; Santa Cruz).

\section{Reverse transcription and PCR analysis}

Total RNA was extracted using TRIzol reagent (Invitrogen), reverse transcribed (ReverTra Ace; Toyobo, Osaka, Japan) and subjected to quantitative real-time PCR (StepOnePlus; Life Technologies) as described (Yoshiko et al. 2007a, Faul et al. 2011). $\beta$-actin (in vivo) or ribosomal protein L32 (in vitro) was used as internal control. Primer and amplicon information is in Table 1.

\section{Histological and morphological assays}

Tissues were fixed in 4\% paraformaldehyde in PBS and plastic sections prepared according to the manufacturer's instructions. Bone mineralization was evaluated using calcein double-labeling (Choi et al. 2017). Plastic sections were also carbon coated, and elemental mapping of magnesium, calcium and phosphorus was performed using electron probe microanalysis with a beam current of $20 \mathrm{nA}$ and an accelerating voltage of $15 \mathrm{kV}$ with an integration time of $0.05 \mathrm{~s}$ at each pixel (JXA-8200; JEOL, Tokyo, Japan) (Suzuki et al. 2008). The RGB (red, green, blue) color intensity was quantified by ImageJ. Decalcified paraffin sections (10\% EDTA in PBS) were used for hematoxylin and eosin or immunofluorescence staining. Frontal sections (thickness, $5 \mu \mathrm{m}$ ), approximately 2-mm from the sagittal suture, were used for histomorphometry. Sections pretreated with Dako protein block (Dako) were incubated with a mixture of polyclonal antibodies against FGF23 and pERK1/2 or with polyclonal antibodies against PHEX (1:60; Santa Cruz Biotechnology) at $4^{\circ} \mathrm{C}$ overnight, followed by incubation with a mixture of Cy2- and/ or Cy3-conjugated (1:400; Jackson ImmunoResearch Laboratories) or Alexa Fluor 594 (1:500; Thermo Fisher Scientific)-conjugated secondary antibodies for $1 \mathrm{~h}$ at room temperature. FGF23- and pERK-positive areas on the sections were quantified by ImageJ. 


\begin{tabular}{|c|c|c|c|c|}
\hline $\begin{array}{l}\text { Journal of } \\
\text { Endocrinology }\end{array}$ & $\begin{array}{l}\text { T Minamizaki, Y Konishi } \\
\text { et al. }\end{array}$ & $\begin{array}{l}\text { sKL causes hypomineralization } \\
\text { in } k / / k / \text { mice }\end{array}$ & $237: 3$ & 288 \\
\hline
\end{tabular}

Table 1 Primer list.

\begin{tabular}{|c|c|c|c|c|}
\hline Species & Target & & Sequence & Size \\
\hline \multirow[t]{12}{*}{ Rat } & Alp & $\mathrm{F}$ & CTG CAA GGA CAT CGC CTA TC & 101 \\
\hline & & $\mathrm{R}$ & CAT CAG TTC TGT TCT TGG GGT A & \\
\hline & Egr-1 & $\mathrm{F}$ & CCT ATG AGC ACC TGA CCA CA & 196 \\
\hline & & $\mathrm{R}$ & AGG CCA CTG ACT AGG CTG AA & \\
\hline & Fgf23 & $\mathrm{F}$ & TAA TAG GGG CCA TGA CCA GA & 145 \\
\hline & & $\mathrm{R}$ & TGA TGC TTC GGT GAC AGG TA & \\
\hline & Klotho & $\mathrm{F}$ & GGGACCACCAGAAGAGATGA & 437 \\
\hline & & $\mathrm{R}$ & TTGGCTACAACCCCGTCTAC & \\
\hline & Phex & $\mathrm{F}$ & СCT CCT ACC AGG CAT CAC AT & 126 \\
\hline & & $\mathrm{R}$ & GGA GGA CTG TGA GCA CCA AT & \\
\hline & $R p / 32$ & $\mathrm{~F}$ & GAT TCA AGG GCC AGA TCC T & 66 \\
\hline & & $\mathrm{R}$ & GCA TGT GCT TGG TTT TCT TG & \\
\hline \multirow[t]{36}{*}{ Mouse } & Actb & $\mathrm{F}$ & TTT TCC AGC CTT CCT TCT TG & 89 \\
\hline & & $\mathrm{R}$ & ACG GAT GTC AAC GTC ACA CT & \\
\hline & $A / p$ & $\mathrm{~F}$ & TGG CCT GGA TCT CAT CAG TA & 75 \\
\hline & & $\mathrm{R}$ & GTG CGG TTC CAG ACA TAG TG & \\
\hline & Bglap & $\mathrm{F}$ & AAG CAG GAG GGC AAT AAG GT & 274 \\
\hline & & $\mathrm{R}$ & ACT TGC AGG GCA GAG AGA GA & \\
\hline & Cyp27b1 & $\mathrm{F}$ & CAG CTT CCT GGC TGA ACT CT & 93 \\
\hline & & $\mathrm{R}$ & GAC CAT ATT GGC CCG TAC C & \\
\hline & Dmp1 & $\mathrm{F}$ & CCC ACG AAC AGT GAG TCA TC & 75 \\
\hline & & $\mathrm{R}$ & GCT GTC CGT GTG GTC ACT AT & \\
\hline & $F g f 2$ & $\mathrm{~F}$ & CAA CCG GTA CCT TGC TAT GA & 119 \\
\hline & & $\mathrm{R}$ & TCC GTG ACC GGT AAG TAT TG & \\
\hline & Fgf23 & $\mathrm{F}$ & TTT GGA TCG CTT CAC TTC AGC & 101 \\
\hline & & $\mathrm{R}$ & ACC AGG TAG TGA TGC TTC TGC & \\
\hline & Fgfr1 & $\mathrm{F}$ & TTT AAG CCT GAC CAC CGA AT & 83 \\
\hline & & $\mathrm{R}$ & TCA GAA GGC ACC ACA GAA TC & \\
\hline & Furin & $\mathrm{F}$ & CCA CCA AGC CCT TTC TAA CA & 90 \\
\hline & & $\mathrm{R}$ & TGC AAA AGG CAC ATC AGA AG & \\
\hline & Galnt3 & $\mathrm{F}$ & GGA GGC AAA CCA TTG ATT CT & 74 \\
\hline & & $\mathrm{R}$ & CGC TGA GCA GAA TAC TCG AA & \\
\hline & Klotho & $\mathrm{F}$ & CAA AAG GGA TGA TGC CAA AT & 144 \\
\hline & & $\mathrm{R}$ & CTG TAG CCC CTA TGC CAC TC & \\
\hline & Mepe & $\mathrm{F}$ & CTC ATG AAG ATG CAG GCT GT & 89 \\
\hline & & $\mathrm{R}$ & CAG CTG CTC CTG TCT TCA TT & \\
\hline & Opn & $\mathrm{F}$ & CCA TGA GAT TGG CAG TGA TT & 89 \\
\hline & & $\mathrm{R}$ & СTC CTC TGA GCT GCC AGA AT & \\
\hline & Phex & $\mathrm{F}$ & ATT GCA CTG GCC CTG TTT AT & 86 \\
\hline & & $\mathrm{R}$ & GCT TGG AAA CTT AGG AGA CCT T & \\
\hline & Rp/32 & $\mathrm{F}$ & AGT TCA TCA GGC ACC AGT CA & 72 \\
\hline & & $\mathrm{R}$ & TGT CAA TGC CTC TGG GTT T & \\
\hline & Slc34a 1 & $\mathrm{~F}$ & CTC ATT GTG GGT GCC CAA CAT GAT G & 90 \\
\hline & & $\mathrm{R}$ & ACC ATG TGT CTC CCA CGG ACT GGA AG & \\
\hline & S/c34a3 & $\mathrm{F}$ & CCA GCT GGA TAG CAG TGT GA & 173 \\
\hline & & $\mathrm{R}$ & TGT CCT CCT CTG GAG ATG CT & \\
\hline & Sost & $\mathrm{F}$ & AAG GGA GTG TGG AAC GAA AG & 112 \\
\hline & & $\mathrm{R}$ & GGT CAG GGT CAG AAA CCC TA & \\
\hline
\end{tabular}

\section{Immunoprecipitation}

Cell lysates prepared in 1\% IGEPAL CA630 and $50 \mathrm{mM}$ Tris- $\mathrm{HCl}$ ( $\mathrm{pH}$ 8.0), were incubated with protein G-conjugated magnetic microbeads (Miltenyi Biotec Inc., San Diego, CA, USA) plus mouse monoclonal antibody against FGFR1 or control IgG for $30 \mathrm{~min}$ on ice under rotary agitation, followed by rinsing and elution to obtain immune complexes in accordance with the manufacturer's recommendations.

\section{DNA microarray}

Total RNA ( $1 \mu \mathrm{g}$; evaluated by RIN value) was extracted from Adv-hFGF23- or Adv- $\beta$ gal-transfected RC cells ( $n=3$ replicates for each) and used for generation of 


\begin{tabular}{l|l|l||c|c|}
$\begin{array}{l}\text { Journal of } \\
\text { Endocrinology }\end{array}$ & $\begin{array}{l}\text { T Minamizaki, Y Konishi } \\
\text { et al. }\end{array}$ & $\begin{array}{l}\text { sKL causes hypomineralization } \\
\text { in Kllkl mice }\end{array}$ & $\mathbf{2 3 7 : 3}$ & 289 \\
\hline
\end{tabular}

second-strand cDNA, and cRNA was amplified with the Oligo dT primer, biotinylated and fragmented with OneCycle Target Labeling and control reagents (Affymetrix), followed by hybridization to the GeneChip Rat Genome 2302.0 Array overnight according to the manufacturer's protocol.

\section{Statistical analysis}

Data are presented as mean \pm S.D. $(n=3-4$ in vitro, $n=5-9$ in vivo). Experiments were repeated a minimum of two times. Statistical differences were analyzed with oneway ANOVA using post hoc Tukey's test for multiple comparisons and $t$-tests for between group comparisons.

\section{Results}

\section{sKL is involved in FGF23 signaling in $\mathrm{kl} / \mathrm{kl}$ bones}

As expected, serum FGF23 (full-length intact FGF23) level was much higher in $k l / k l$ compared to WT mice (Fig. 1A, Supplementary Fig. 1A, see section on supplementary data given at the end of this article), as were levels of serum calcium (Fig. 1B), phosphate (Fig. 1C) and 1 $\alpha, 25$-dihydroxyvitamin $\mathrm{D}_{3}$ (1,25D) (Fig. 1D). Fgf23 expression (Fig. 1E) and accumulation (Fig. 1F) in bone and kidney was also higher in $\mathrm{kl} / \mathrm{kl}$ compared to WT mice. Notably, administration of sKL to $k l / k l$ mice increased ERK1/2 phosphorylation (pERK1/2) in bone but not kidney (Fig. 1G) and did not change serum
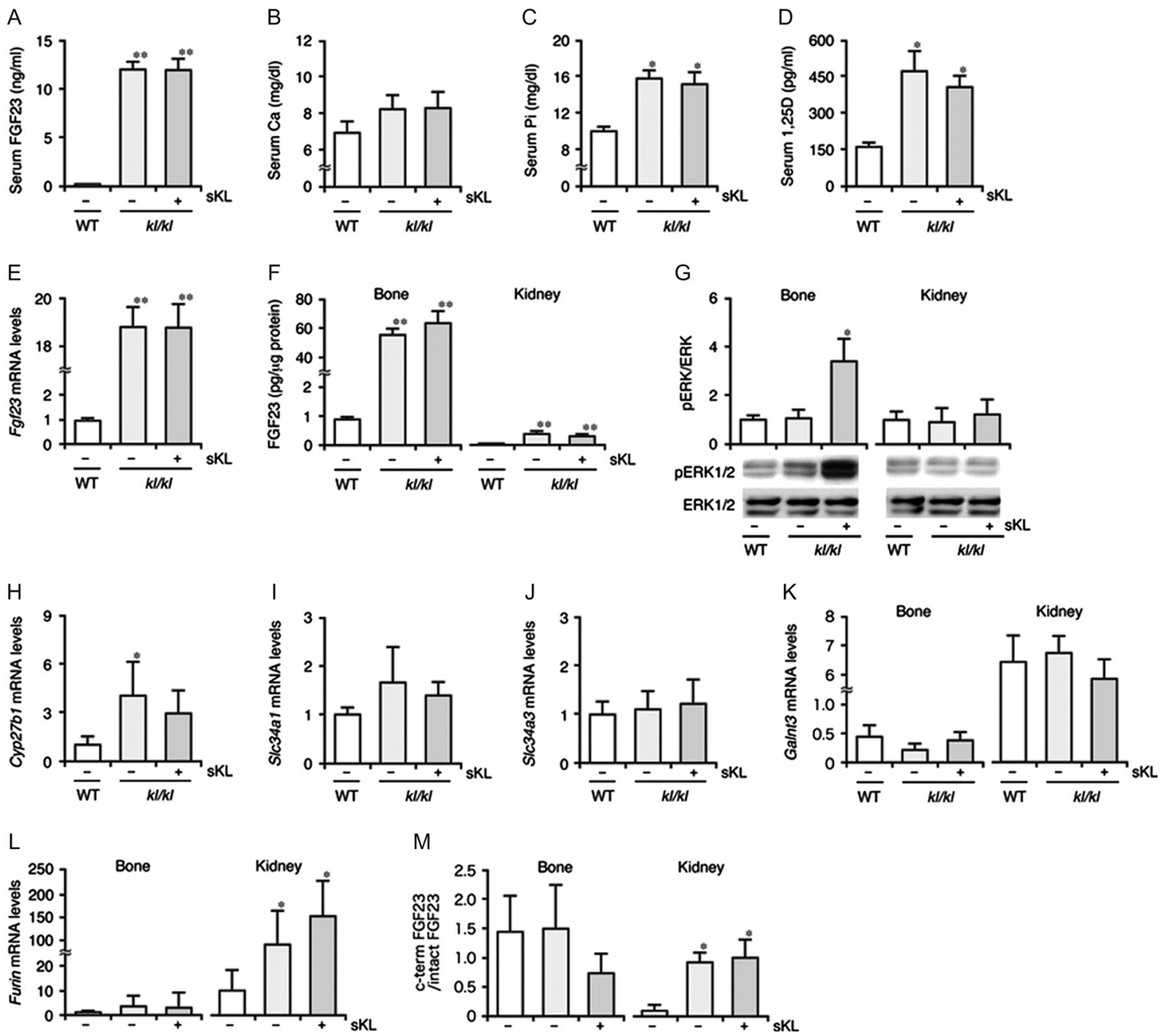

Figure 1

Recruitment of sKL increases ERK1/2 activation in parietal bones of $k / / k /$ mice without changes in serum calcium and phosphate levels. Serum FGF23 (A), calcium (Ca) (B), phosphate (Pi) (C) and 1,25D (D) levels. FGF23 levels in bones and kidneys (F). mRNA levels of Fgf23 in bones (E); Cyp27b1 (H), S/c34a1 (I) and S/c34a3 (J) in kidneys; Galnt3 (K) and Furin (L) in bones and kidneys. (G) ERK1/2 phosphorylation in bones and kidneys. The following panels in (G) provide representative blotting images for each group. pERK1/2, phosphorylated ERK1/2. Values in $(E, G, H, I, J, K$ and $L$ ) are relative to the wild-type (WT), which is set at 1.0. Data represent mean \pm s.D. ${ }^{*} P<0.05$ and ${ }^{*} P<<0.01$, compared to WT mice. $n=9$. 
parameters tested. As for the renal FGF23 target genes, Cyp27b1 levels were higher in $k l / k l$ than in WT mice (Fig. 1H), while Slc34a1 (Fig. 1I) and Slc34a3 (Fig. 1J) were equally expressed among all groups. Neither the Klotho deficiency in $\mathrm{kl} / \mathrm{kl}$ mice nor sKL supplementation had any significant effect on the levels of Galnt 3 mRNA whose product ( $\mathrm{N}$-acetylgalactosaminyltransferase 3 ) O-glycosylates FGF23 to prevent proteolytic processing by the subtilisin-like proprotein convertase FURIN in bone and kidney (Fig. 1K) (Kato et al. 2006, Frishberg et al. 2007, Tagliabracci et al. 2014). Furin mRNA levels (Fig. 1L) were significantly higher in kidney but not bone of $k l / k l$ mice. sKL had no effect on the reduced weight gain exhibited by $k l / k l$ compared to WT mice (Supplementary Fig. 1B). Short-term treatment of WT mice with sKL had no effect on serum parameters, gene expression in kidney or bone or bone parameters (see below; data not shown).

\section{sKL potentiates ERK signaling in bones of normal Klotho-expressing mice treated with 1,25D}

To determine whether sKL elicits similar responses to those seen in $\mathrm{kl} / \mathrm{kl}$ mice in normal Klotho-expressing mice treated with 1,25D, we treated C57BL/6J mice with 1,25D followed by a single injection of sKL. As expected (Kolek et al. 2005, Yamamoto et al. 2010), 1,25D increased not only Fgf23 expression (Fig. 2A) and accumulation (Fig. 2B) in bone, but also increased levels of serum FGF23 (Fig. 2C) and calcium (Fig. 2D). 1,25D treatment had no effect on serum phosphate levels (Fig. 2E), but decreased levels of the FGF23 target genes in kidney (see above) (Fig. 2F, G and H)
A

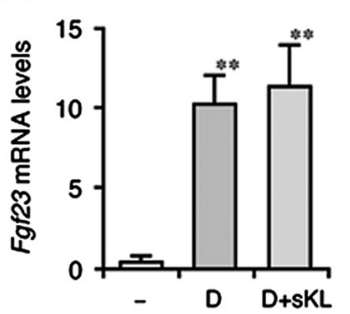

D
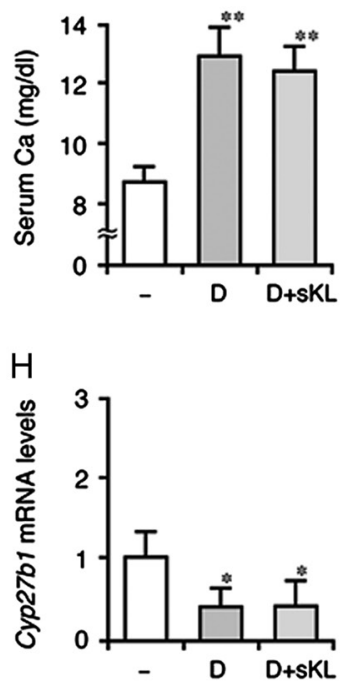

B

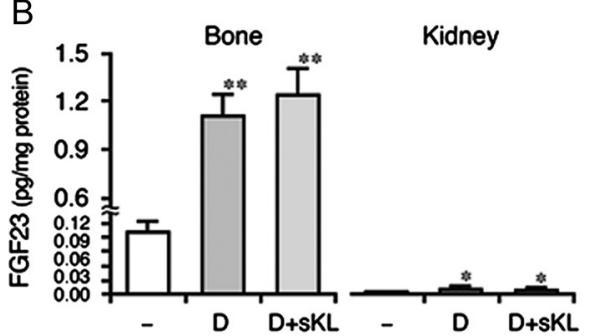

E

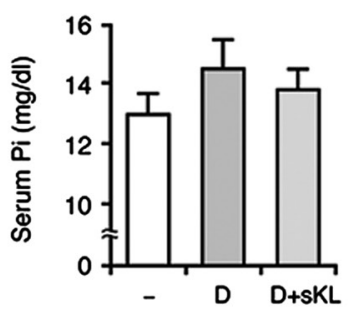

I

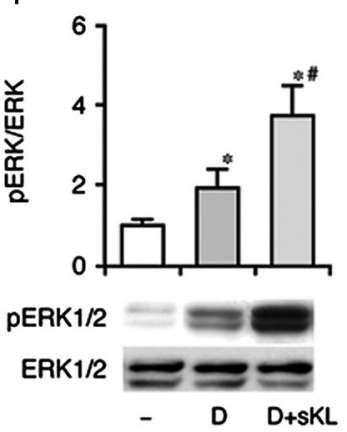

$\mathrm{F}$

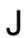

C
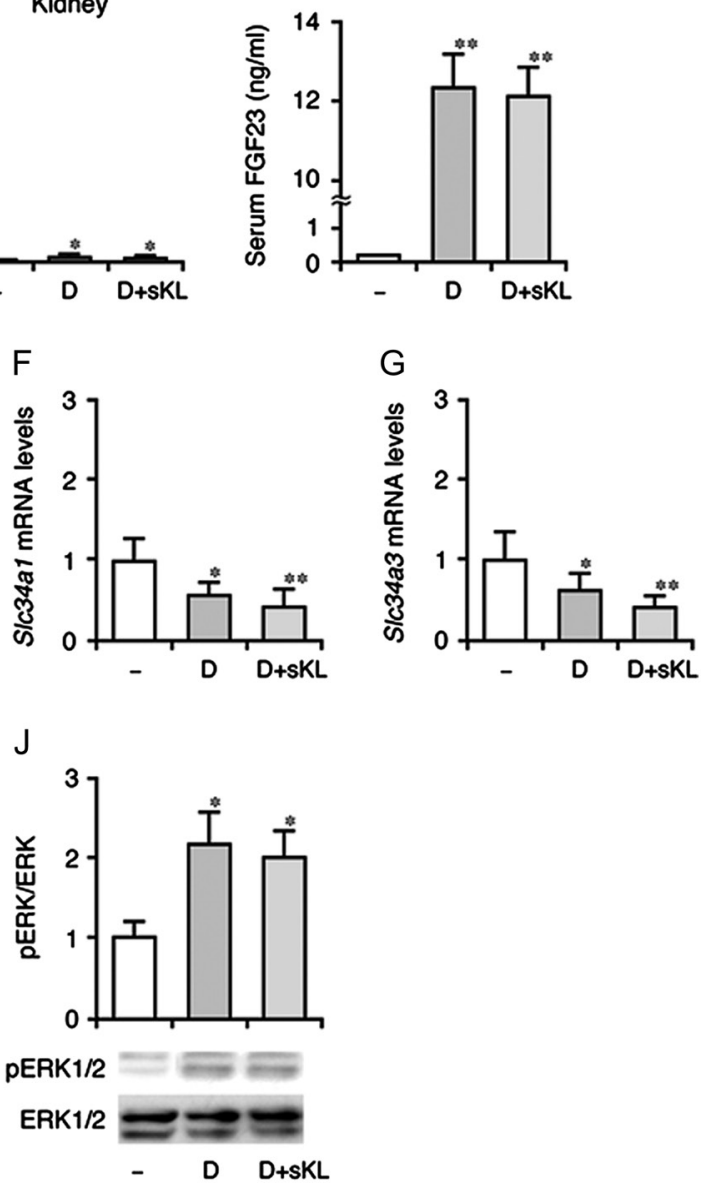

Figure 2

A single intravenous administration of sKL to normal mice pretreated with 1,25D increased ERK1/2 activation in parietal bones. Fgf23 mRNA levels in bones (A) and FGF23 levels in bones, kidneys (B) and sera (C). Serum calcium (Ca) (D) and phosphate (Pi) (E) levels. mRNA levels of S/c34a1 (F), S/c34a3 (G) and Cyp27b1 $(\mathrm{H})$ in kidneys. ERK1/2 phosphorylation in bones $(\mathrm{I})$ and kidneys $(\mathrm{J})$. pERK1/2, phosphorylated ERK1/2. Panels (I and J) are representative blotting images for each group. Values in $(A, F, G, H, I$ and $J)$ are relative to vehicle control is set at 1.0. Data represent mean \pm s.D. ${ }^{*} P<0.05$ and $* * P<0.01$, compared to vehicle control. ${ }^{*} P<0.05$, compared to $1,25 \mathrm{D}$ alone. $n=6$. -, vehicle control; $\mathrm{D}, 1,25 \mathrm{D}$ alone; $\mathrm{D}+\mathrm{sKL}$, $1,25 \mathrm{D}$ plus sKL, respectively. 
and increased pERK1/2 in bone and kidney (Fig. 2I and J). Notably, the 1,25D-induced increase in pERK1/2 in bone was further enhanced by sKL treatment within $2 \mathrm{~h}$ (Fig. 2I and J). Thus, exogenously added sKL activates the ERK pathway in not only $\mathrm{kl} / \mathrm{kl}$ but also normal bone.

\section{sKL causes mineralization defects in $\mathrm{kl} / \mathrm{kl}$ bones}

Given that sKL activated ERK1/2 in bone of $\mathrm{kl} / \mathrm{kl}$ mice, we hypothesized that sKL might improve the skeletal anomalies seen in $k l / k l$ mice. However, electron probe X-ray microanalysis of parietal bones revealed lower calcium and phosphorus and higher magnesium signals in bones of sKL-treated $\mathrm{kl} / \mathrm{kl}$ mice vs in WT or vehicletreated $k l / k l$ mice (Fig. 3A and Supplementary Fig. 2). Reduced calcein double-labeling (Fig. 3B) and increased osteoid thickness (Fig. 3C and D) paralleled the electron probe X-ray microanalysis data. sKL treatment had no detectable effect on osteoblast number (Fig. 3E), osteocyte number (Fig. 3F) or bone thickness (Fig. 3G). Osteoblasts and osteocytes were markedly FGF23 positive in $k l / k l$ but not WT bone, with intense FGF23-pERK co-expression in bone of sKL-treated mice (Fig. 4A). Concomitantly, the expression of the osteoblast/osteocyte marker genes (Fig. 4B, C, D, E, F and G) with the exception of Bglap (Fig. 4D) tended to be higher in $\mathrm{kl} / \mathrm{kl}$ compared to WT bone,

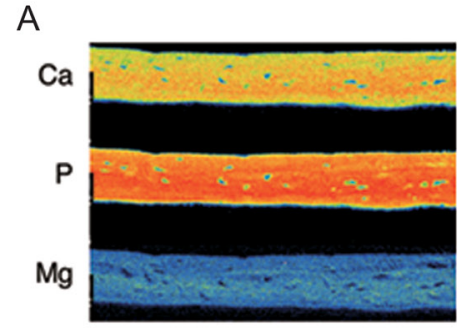

WT
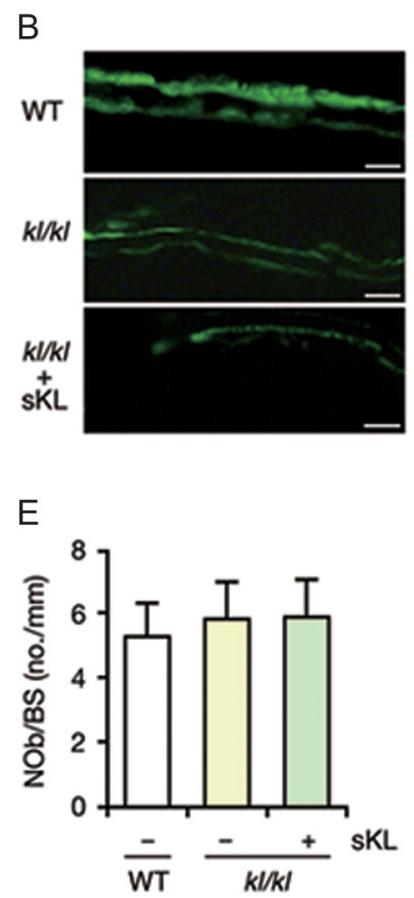

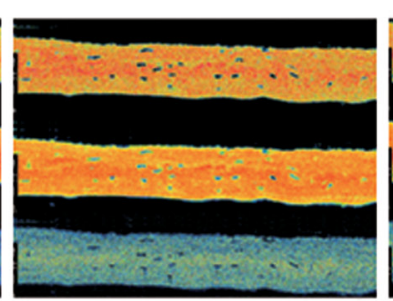

$k l / k l$

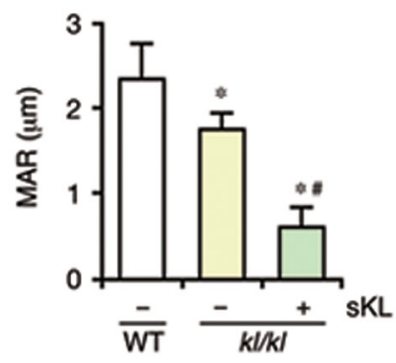

F

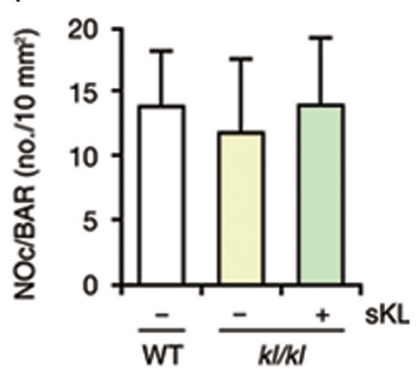

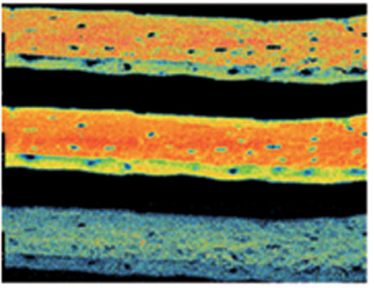

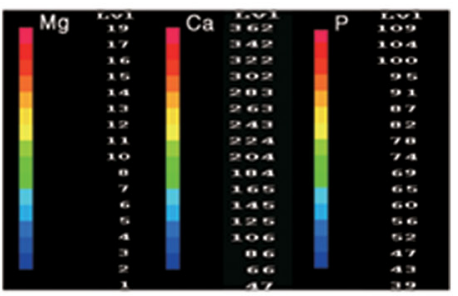

$k l / k l+s K L$

C
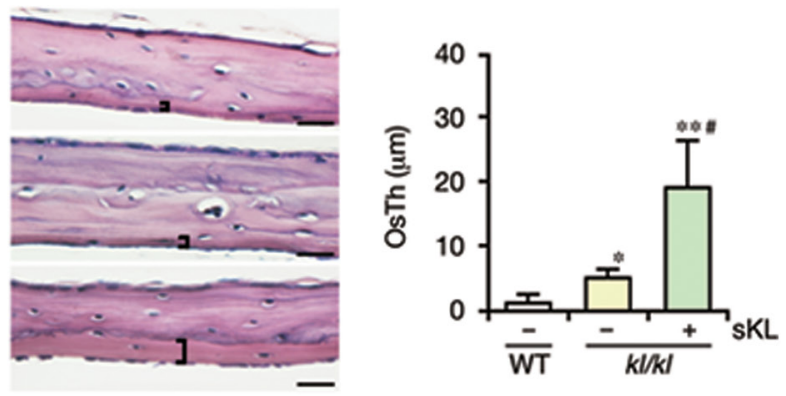

G

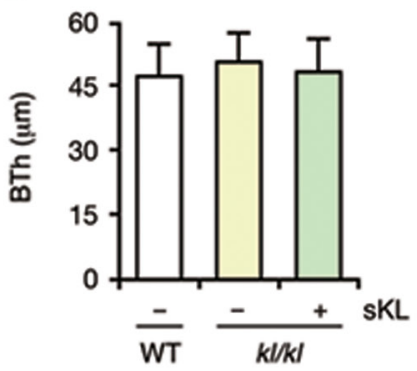

Figure 3

Recruitment of sKL caused hypomineralization in parietal bones of $k l / k l$ mice. Representative images of frontal plastic (A and B) and decalcified paraffin (C) sections. (A) Elemental mapping of calcium (Ca), phosphorus (P) and magnesium (Mg). Right panel shows a color index for the level of each element. (B) Calcein double labeling and calculated mineral apposition rate (MAR). (C) Hematoxylin and eosin staining. The parentheses in the figure indicate the osteoid. Scale bar, $5 \mu \mathrm{m}$ (B) and $25 \mu \mathrm{m}$ (C). Histomorphometry analysis of unmineralized osteoid thickness (OsTh) (D), number of osteoblasts per bone surface (NOb/BS) (E), osteocyte lacunae per bone area (NOC/BAR) (F) and bone thickness (BTh) (G). * $P<0.05$ and $* P<0.01$, compared to wild-type (WT) mice that received the vehicle. ${ }^{\# P}<0.05$, compared to $\mathrm{kl} / \mathrm{k} /$ mice that received the vehicle. $n=9$. A full color version of this figure is available at https://doi. org/10.1530/JOE-17-0683. 


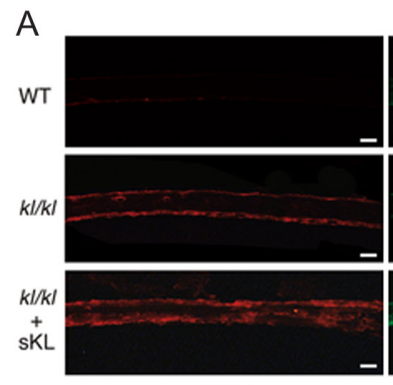

FGF23

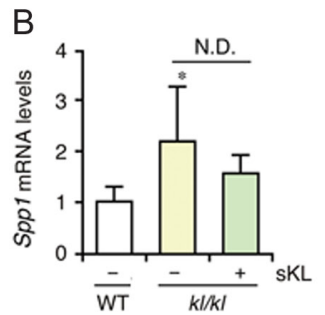

G

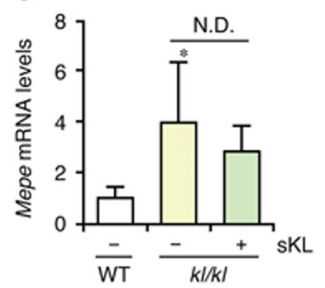

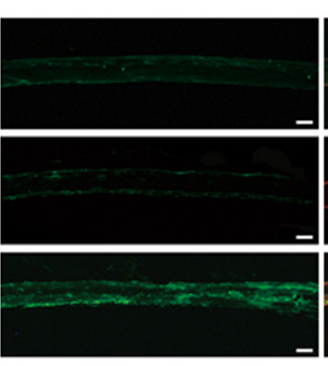

pERK

C

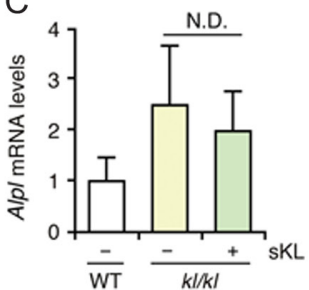

$\mathrm{H}$

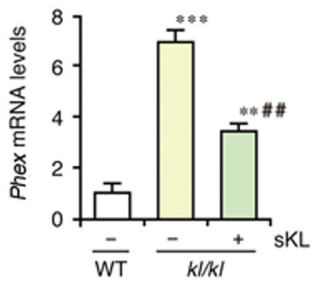

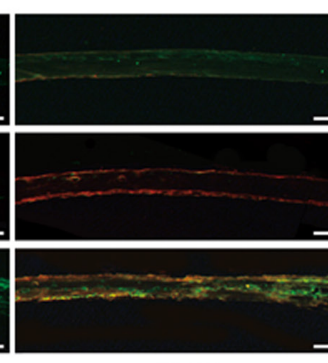

Merge
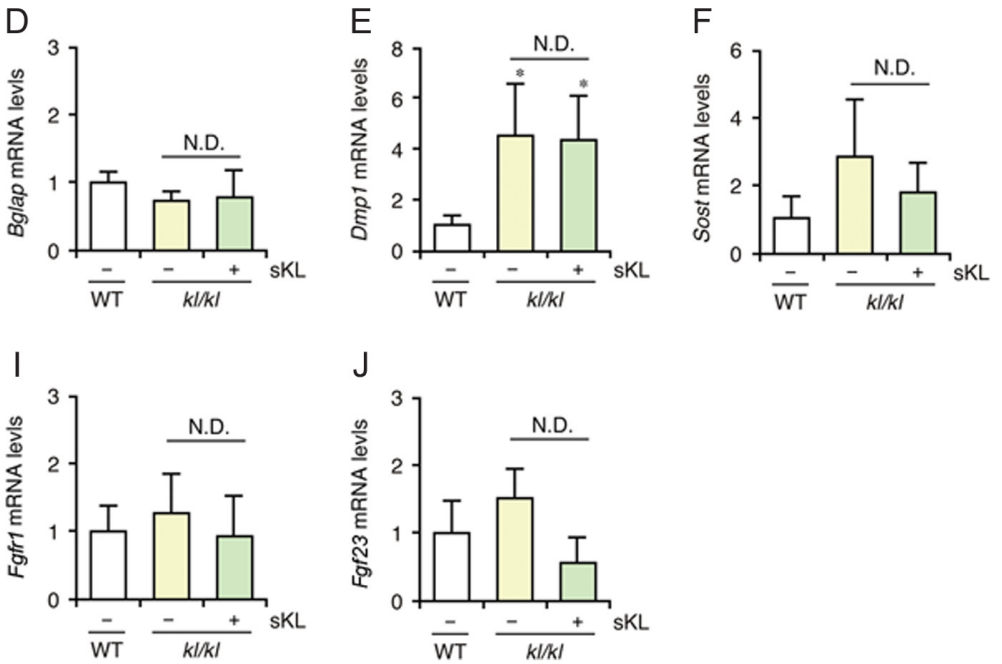
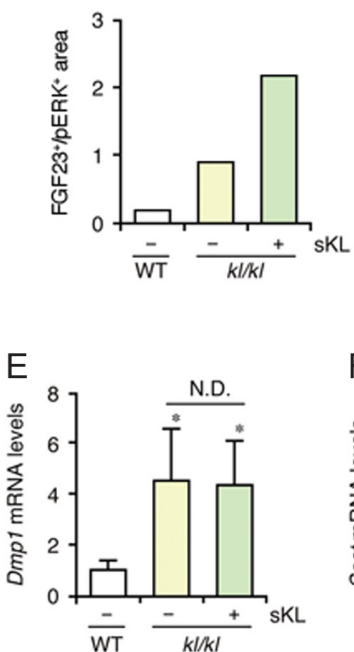

$\mathrm{J}$

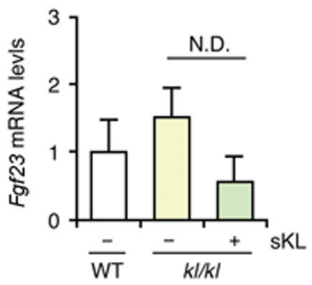

Figure 4

Recruitment of Klotho increased ERK activation in the parietal bones of $k l / k l$ mice. (A) Representative images of immunofluorescence staining of FGF23-positive osteoblasts/osteocytes costained with anti-phosphorylated ERK (pERK) antibodies. Decalcified paraffin sections of parietal bones were used, as shown in Fig. 3C. Scar bars, $25 \mu \mathrm{m}$. (B, C, D, E, F, G, H, I and J) mRNA levels of osteoblast/osteocyte-associated genes. Values are relative to wild-type (WT) mice as controls that are set at 1.0. Data represent mean \pm s.D. ${ }^{*} P<0.05$, compared to WT mice that received the vehicle. $n=9$. A full color version of this figure is available at https://doi.org/10.1530/JOE-17-0683.

with Spp1 (Fig. 4B), Dmp1 (Fig. 4E), Mepe (Fig. 4G) and Phex (Fig. 4H) significantly higher; of these, only Phex was decreased significantly by sKL treatment. No significant changes were detectable in Fgfr1 mRNA expression under any condition.

\section{sKL directly promotes FGF23 signaling and hypomineralization of bone in vitro}

To determine whether sKL directly regulates FGF23dependent signaling in bone, we assessed $\mathrm{kl} / \mathrm{kl}$ and WT mouse calvaria cells in osteogenic medium in vitro. $\mathrm{kl} / \mathrm{kl}$ calvaria cells exhibited intrinsic anomalies with fewer ALP-positive (ALP+) cells (Fig. 5A) and lower matrix mineralization (Fig. 5B) than their WT counterparts. FGF23 was very low to undetectable in both WT and $k l / k l$ cells (Fig. 5C), with undetectable expression of Klotho but elevated levels of Fgf23 mRNA in bones (Fig. 5D). These results suggest that the intrinsic defects in $\mathrm{kl} / \mathrm{kl}$ osteoblasts are independent of FGF23 levels. Consistent with this possibility, although FGF23 production was high in $\mathrm{kl} / \mathrm{kl}$ up to at least $48 \mathrm{~h}$ in calvaria organ cultures (Fig. 5E), expression of early growth response-1 (Egr-1), another marker of FGF23 signaling (Kurosu et al. 2006) (Fig. 5F) and pERK1/2 (Fig. 5G) was increased in $\mathrm{kl} / \mathrm{kl}$ calvaria organ cultures only on treatment with sKL. Similarly, Egr-1 expression (Fig. 5H) and ERK1/2 activation (Fig. 5I) were seen in the RC cell osteogenic model only when sKL was used in combination with FGF23. These results indicate that sKL directly promotes FGF23 signaling in bones.

\section{Phex is a downstream effector of sKL-FGF23-FGFR signaling in osteoblasts}

To identify the gene(s) acting downstream of sKLFGF23-FGFR signaling in osteoblasts-osteocytes, we used the RC cell model during mineralization phase of culture (Minamizaki et al. 2009). We first confirmed that 


\begin{tabular}{l|l|l|l|l|}
$\begin{array}{l}\text { Journal of } \\
\text { Endocrinology }\end{array}$ & $\begin{array}{l}\text { T Minamizaki, Y Konishi } \\
\text { et al. }\end{array}$ & $\begin{array}{l}\text { sKL causes hypomineralization } \\
\text { in Kllkl mice }\end{array}$ & $\mathbf{2 3 7 : 3}$ & $\mathbf{2 9 3}$ \\
\hline
\end{tabular}

A

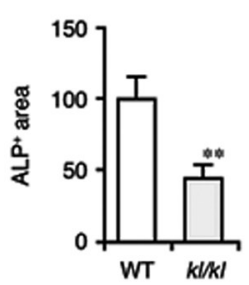

B

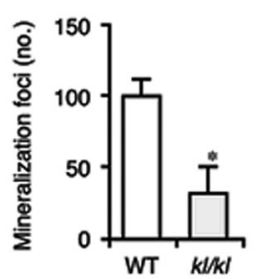

C

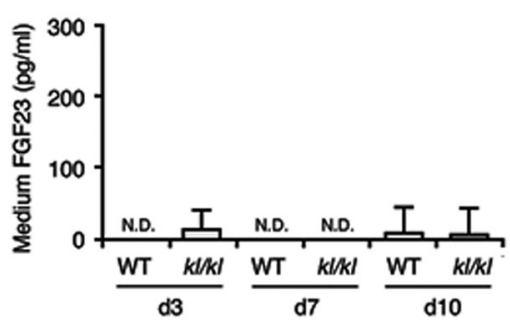

D

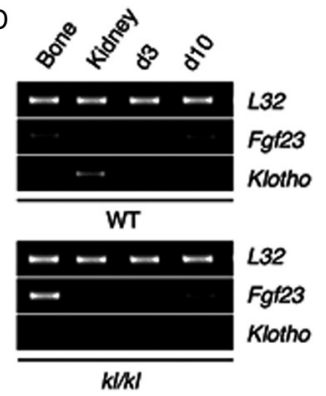

E

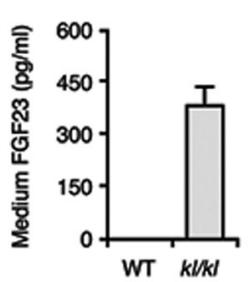

$\mathrm{F}$

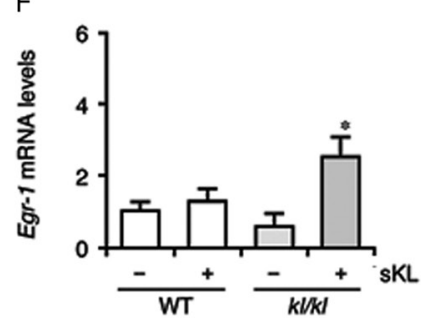

G

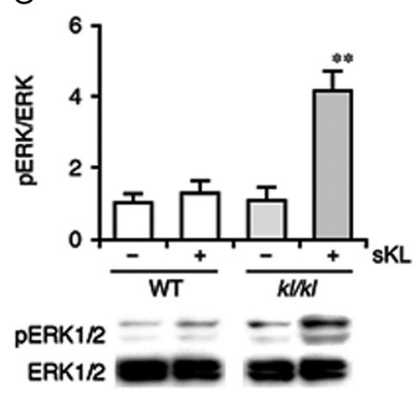

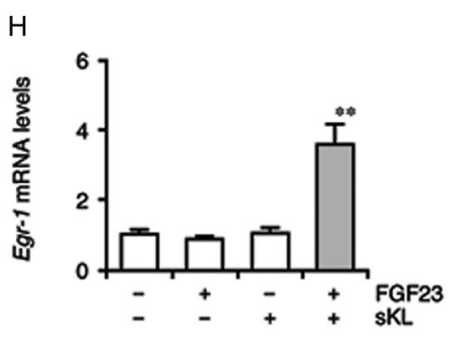

।

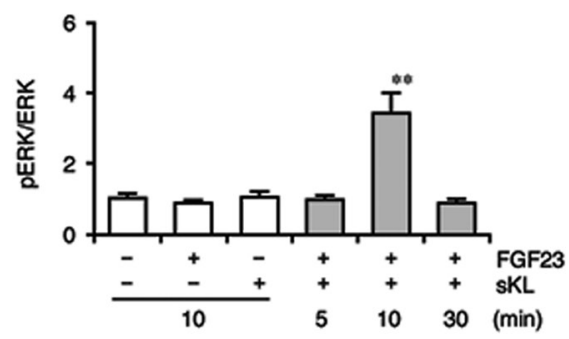

PERK1/2 ERK $1 / 2$
$\mathrm{J}$

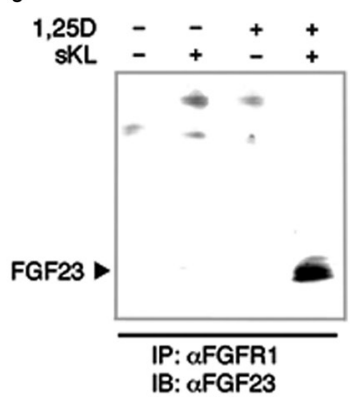

Figure 5

SKL contributed to FGF23 signaling in bones, resulting in decreased matrix mineralization. (A, B, C and D) Calvaria cell cultures of WT and $k l / k l$ mice. Alkaline phosphatase-positive (ALP+) area (A) and mineralization foci (B). (C) FGF23 levels in culture media of WT and $k l / k l$ as indicated in time (day). Data represent mean \pm S.D. ${ }^{*} P<0.05$ and $* * P<0.01$, compared to WT mice. $n=8-9$. (D) mRNA expression of $F g f 23$ and $K /$ totho in bones and kidneys at day3 (d3) and day10 (d10). (E, F and G) Parietal bones from newborn WT or kl/kl mice. (E) Medium FGF23 concentrations, Egr-1 mRNA levels (F), and ERK1/2 phosphorylation (G). Panels below (G) are representative blotting images for each group. Data represent mean \pm s.D. ${ }^{*} P<0.05$ and $* \star P<0.01$, compared to matched vehicle control $(-) . n=4$. ( $\mathrm{H}, \mathrm{I}$ and J) Fetal RC cells. Egr-1 mRNA levels (H) and ERK1/2 phosphorylation (I). Panels below are representative blotting images for each group. (J) Immunoblotting (IB) with polyclonal anti-FGF23 antibody ( $\alpha$ FGF23) after immunoprecipitation (IP) with monoclonal anti-FGFR1 antibody ( $\alpha$ FGFR1). Data represent mean \pm S.D. ${ }^{*} * P<0.01$, compared to matched vehicle control $(-)$. $n=4$.

endogenous FGF23 coprecipitated FGFR1 in the presence of sKL in RC cells pretreated with 1,25D (Fig. 5J). Second, we confirmed that matrix mineralization is defective in RC cells when they are treated with sKL plus FGF23 (Fig. 6A). Of more than 31,000 genes screened by microarray analysis, 52 genes were differentially expressed in sKL-FGF23-treated vs -untreated RC cells; of these, 16 genes were downregulated (Table 2). Of these sixteen genes, only Phex has previously been implicated in bone mineralization, with Phex haploinsufficiency causing osteomalacia/XLH rickets in mice and humans (Guo \&
Quarles 1997, Miao et al. 2001). qRT-PCR confirmed that sKL downregulated Phex in both RC cell culture (Fig. 6B) and $k l / k l$ bone organ culture (Fig. 6C) models. As expected based on its activity to stimulate FGF23 (Kolek et al. 2005, Yamamoto et al. 2010), 1,25D also downregulated Phex in the RC cell model (Fig. 6D). Treatment of RC cells with soluble PHEX (sPHEX) in the presence of sKL and FGF23 rescued the hypomineralization caused by sKL and FGF23 (Fig. 6E). Finally, the sKL-FGF23-induced hypomineralization of RC cell cultures was also rescued by U0126, an inhibitor of ERK activation involved FGF23 
A

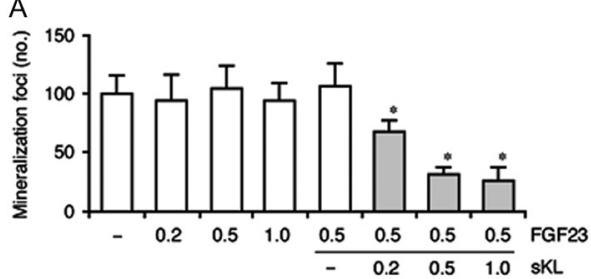

B

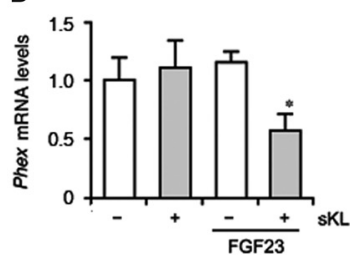

C
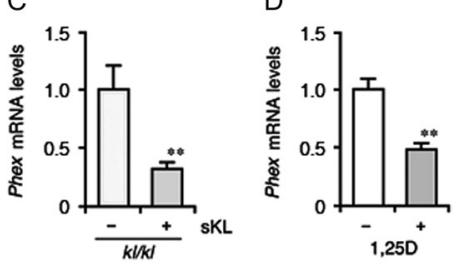

$E$

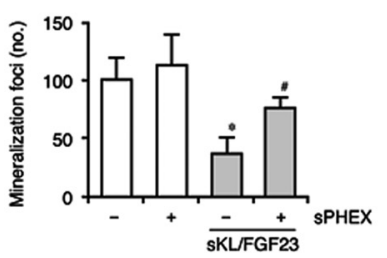

$\mathrm{F}$

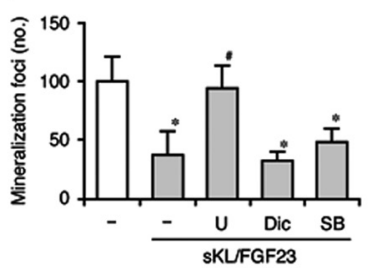

Figure 6

PHEX is a downstream target of sKL and FGF23 in the bones. (A, E and F) The number of mineralized foci in fetal rat calvarial $(R C)$ cell cultures. $X$-axis values in (A), $\mu \mathrm{g} / \mathrm{mL}$. ( $B, C$ and $D)$ Phex mRNA levels in RC cells. Values are relative to matched controls, which is set at 1.0. (E) SPHEX, soluble PHEX. (F) U, U0126 (U); Dic, dicumarol; and SB, SB203580. Data represent mean \pm S.D. ${ }^{*} P<0.05$ and $* * P<0.01$, compared to matched vehicle control $(-) ;{ }^{\#}<<0.05$, compared to sKL/FGF23. $n=4$.

signaling, but not the c-JNK inhibitor dicumarol or the p38 MAP kinase inhibitor SB203580 (Fig. 6F). Taken together, our findings suggest that sKL-FGF23 induces ERK1/2 activation in bone leading to downregulation of Phex and hypomineralization.

\section{Discussion}

Much remains to be understood about the relationship between sKL, the Klotho-FGF23 axis and mineralization of bone. In this study, we assessed the effects of exogenously added sKL on bone and osteoblasts using Klotho-deficient $(k l / k l)$ mice and cell and organ cultures. We found that sKL-induced FGF23 signaling and ERK1/2 activation in bone and exacerbated the $\mathrm{kl} / \mathrm{kl}$ hypomineralization defect without exacerbating the hyperphosphatemia, hypercalcemia or hypervitaminosis D seen in these mice. We also report that sKL formed a complex with FGF23 and FGFR, caused ERK1/2-dependent downregulation of Phex and that the sKL-FGF23-dependent hypomineralization was rescued by treatment with soluble PHEX in vitro. These data suggest that exogenously added sKL participates directly in FGF23 signaling in bone and that PHEX is a downstream effector of the sKL-FGF23-FGFR axis in bone (Fig. 7).

Interactions among the type I membrane protein Klotho, FGF23 and FGFR1 suggest that the target cells of FGF23 express Klotho, as seen in kidney (Kurosu et al. 2006, Urakawa et al. 2006, Ben-Dov et al. 2007, Lindberg et al. 2014). Klotho expressed in osteocytes has been reported to play a key role in bone mineralization (Komaba et al. 2017), in spite of 500 times lower Klotho in bone than kidney (Rhee et al. 2011) and undetectable Klotho expression in osteoblasts (Fig. 5). Such reports highlight the need to better understand the potential mechanisms by which FGF23 regulates bone mineralization. Consistent with several studies (Goetz et al. 2010, Shalhoub et al. 2011, Smith et al. 2012, Kawai et al. 2013), we found that sKL participates in FGF23-dependent signaling, and in particular, we report that sKL negatively regulates bone mineralization both in normal bone cell models and in the complete absence of Klotho in $\mathrm{kl} / \mathrm{kl}$ mice. Taken together, the data raise questions about how extensively sKL contributes to FGF23-dependent signaling in bones under normal and pathological conditions. The finding that $\mathrm{Fg} f 23$ expression in bones is dependent on the circadian clock system (Kawai et al. 2014) further highlights the need for additional studies.

Although sKL forms a complex with FGF23 and FGFRs and subsequently promotes FGF23 signaling in a variety of cells, including NIH3T3 cells treated with increasing concentrations of FGF23 and sKL (Smith et al. 2012) and human embryonic kidney 293 cells overexpressing FGF23 and sKL (Kawai et al. 2013), our relatively shortterm treatment protocols with sKL inhibited bone mineralization without affecting renal FGF23 target genes or changing serum calcium and phosphate levels in the models used here. Similarly, short-term treatment with sKL did not rescue serum phosphate levels or affect expression of renal FGF23 target genes in neonatal Hyp mice, a mouse model of XLH (Kawai et al. 2013) nor did sKL enhance the effect of FGF23 treatment alone in kidney slices ex vivo (Andrukhova et al. 2017). Longer-term administration (intraperitoneally) of sKL has also been shown to rescue ectopic calcification without changes in serum calcium and phosphate levels in $\mathrm{kl} / \mathrm{kl}$ mice (Chen et al. 2013); whether short-term administration of sKL also has an inhibitory effect on ectopic mineralization in $\mathrm{kl} / \mathrm{kl}$ mice seems plausible but remains to be determined. Indeed, chronic sKL overexpression driven by a liver-specific 


\begin{tabular}{l|l|l||c|c|}
$\begin{array}{l}\text { Journal of } \\
\text { Endocrinology }\end{array}$ & $\begin{array}{l}\text { T Minamizaki, Y Konishi } \\
\text { et al. }\end{array}$ & $\begin{array}{l}\text { sKL causes hypomineralization } \\
\text { in Kllkl mice }\end{array}$ & $\mathbf{2 3 7 : 3}$ & 295 \\
\hline
\end{tabular}

Table 2 Microarray analysis.

\begin{tabular}{|c|c|c|c|}
\hline \multirow[b]{2}{*}{ Gene } & \multicolumn{2}{|c|}{ Intensity } & \multirow[b]{2}{*}{ Fold change (log) } \\
\hline & $\beta$-gal & FGF23 & \\
\hline \multicolumn{4}{|l|}{ Upregulated } \\
\hline RT1-EC2 & 18.3 & 50.2 & 1.7 \\
\hline Transcribed locus & 59.7 & 167.2 & 1.4 \\
\hline Transcribed locus & 384.5 & 997.7 & 1.4 \\
\hline$E g \ln 3$ & 13.1 & 31.9 & 1.4 \\
\hline$S I \times 1 b$ & 55.3 & 153.9 & 1.3 \\
\hline S100a13 & 53.6 & 154.3 & 1.3 \\
\hline$R T 1-E C 2$ & 10.1 & 24.9 & 1.3 \\
\hline Gnb1 & 99.4 & 271 & 1.3 \\
\hline Cdkn1a & 238.1 & 500.6 & 1.3 \\
\hline Transcribed locus & 204.4 & 456.9 & 1.2 \\
\hline Transcribed locus & 63.6 & 190.3 & 1.2 \\
\hline Mnf1 & 269.3 & 624.4 & 1.2 \\
\hline$C k l f$ & 22.8 & 54.4 & 1.2 \\
\hline Atox 1 & 185.5 & 425.3 & 1.2 \\
\hline (miscRNA) & 64.6 & 131.5 & 1.2 \\
\hline Ubl7 & 63.4 & 124.9 & 1.1 \\
\hline RGD1565641 & 265.8 & 663.2 & 1.1 \\
\hline Lcp 1 & 11.7 & 28.6 & 1.1 \\
\hline Emg1 & 74.4 & 144 & 1.1 \\
\hline Usmg5 & 931.1 & 1821.5 & 1 \\
\hline Transcribed locus & 33.6 & 67.9 & 1 \\
\hline TLOABA24YI10 & 436.4 & 775.6 & 1 \\
\hline Slirp & 200.6 & 410.5 & 1 \\
\hline $\operatorname{Rps} 25$ & 1364.4 & 2846.6 & 1 \\
\hline RGD1309621 & 555.2 & 1161 & 1 \\
\hline RGD1309621 & 259.3 & 447.6 & 1 \\
\hline Polr2l & 337.7 & 538.4 & 1 \\
\hline Polr2i & 245.5 & 489.6 & 1 \\
\hline Nop10 & 772.2 & 1506.6 & 1 \\
\hline Ndufa11 & 407.7 & 844.9 & 1 \\
\hline Mrp/14 & 29.1 & 50.5 & 1 \\
\hline Eif3k & 604.9 & 1283.7 & 1 \\
\hline Csde1 & 440 & 871.6 & 1 \\
\hline Churc1 & 432.1 & 909.2 & 1 \\
\hline Atp5j2 & 632.8 & 1253.6 & 1 \\
\hline \multicolumn{4}{|l|}{ Downregulated } \\
\hline$R d x$ & 250.8 & 97.1 & -1.3 \\
\hline Phex & 133.9 & 68.3 & -1.2 \\
\hline Transcribed locus & 251.3 & 105.7 & -1.2 \\
\hline Zfp422 & 108.6 & 58.9 & -1.2 \\
\hline Transcribed locus & 38.3 & 17 & -1.2 \\
\hline $\mathrm{Fg} / 2$ & 34.5 & 12.7 & -1.2 \\
\hline Transcribed locus & 205.8 & 96.7 & -1.2 \\
\hline Ythdf2 & 628.7 & 247.1 & -1.1 \\
\hline Transcribed locus & 91.6 & 43.8 & -1.1 \\
\hline Dusp6 & 111.5 & 48.5 & -1.1 \\
\hline Transcribed locus & 145.5 & 62.4 & -1.1 \\
\hline Transcribed locus & 65.6 & 33 & -1.1 \\
\hline $\operatorname{Lin} 7 c$ & 232.2 & 120.4 & -1 \\
\hline Transcribed locus & 749 & 386.2 & -1 \\
\hline Transcribed locus & 67.1 & 44.1 & -1 \\
\hline Transcribed locus & 76.4 & 37.9 & -1 \\
\hline
\end{tabular}

promoter in mice resulted in osteomalacia, although this was accompanied by hypophosphatemia, hypocalcemia and markedly increased FGF23, making it difficult to separate sKL effects in kidneys vs bones (Smith et al.
2012). Taken together, these results suggest that sKL may not support the actions of FGF23 in kidney, at least under pathologic conditions such as when Klotho or PHEX are deficient or when FGF23 is overexpressed. In Hyp mice, 


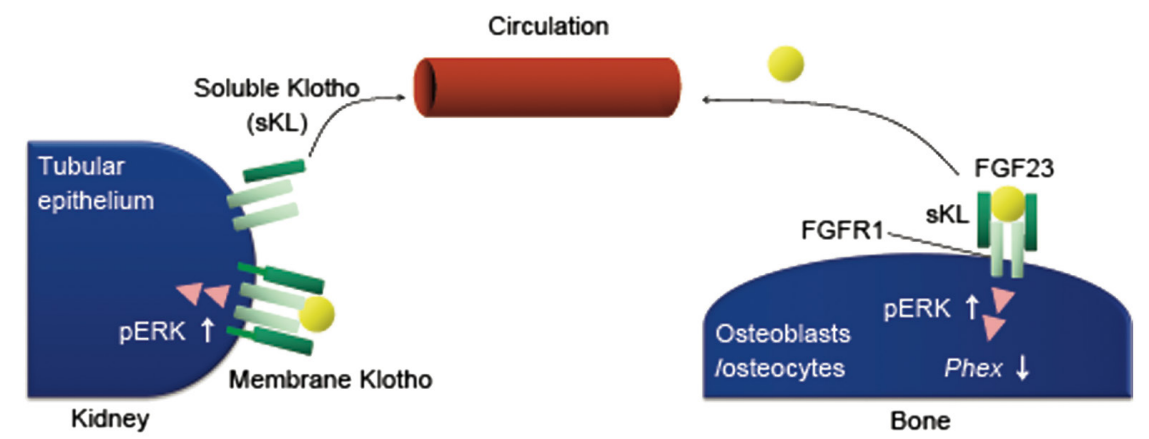

\section{Figure 7}

A schematic summary of the circulation and function of sKL and FGF23. sKL, truncated from membrane Klotho in kidneys, circulates and acts in bones but not kidneys, by forming a complex with FGFR1 and FGF23, which is expressed in bone. This upregulates ERK $1 / 2$ signaling, resulting in the downregulation of Phex in osteoblastsosteocytes and resultant hypomineralization of bone. A full color version of this figure is available at https://doi.org/10.1530/JOE-17-0683. an excess of osteocytic FGF23 contributes to pyrophosphate accumulation and the resultant mineralization defect through the downregulation of tissue-nonspecific ALP (Murali et al. 2016). In our models, the elevated levels of Furin mRNA in kidney may degrade FGF23, yielding more than a 100-fold difference in FGF23 levels between bone and kidney. The abundant FGF23 in bone may thus provide a suitable environment for complex formation of sKL, FGF23 and FGFRs.

Andrukhova and colleagues reported that FGF23 modulates PTH function via ERK1/2 phosphorylation in bone and kidney (Andrukhova et al. 2016). The fact that sKL plus FGF23 treatment upregulates ERK1/2 and $E g r-1$ in bone and osteoblastic cells is in keeping with the observation that they are involved in FGF23 signaling in kidneys, parathyroid and chondrogenic cells (Urakawa et al. 2006, Ben-Dov et al. 2007, Kawai et al. 2013). However, results reported for ERK involvement in bone matrix mineralization have been somewhat contradictory, with ERK sometimes reported as a negative regulator and sometimes a positive regulator of matrix mineralization, likely due to the difficulty of completely separating the effects of ERK on osteoblast differentiation vs matrix mineralization in some models and protocols. For example, studies with transgenic mice overexpressing either a dominant negative Mek1 or constitutively active Mek1 driven by the osteocalcin promoter crossed with Runx2+/mice suggested that ERK-MAPK activation stimulates osteoblast differentiation and skeletal development through a pathway involving RUNX2 (Ge et al. 2007). On the other hand, when Kono et al. used approaches of chemical inhibition and infection with adenovirus vectormediated dominant negative Ras or constitutively active Mek1 in MC3T3-E1 cells, MLO-A5 pre-osteocytic cells and over the calvaria of neonatal mice, they concluded that ERK is a negative regulator of matrix mineralization (Kono et al. 2007). Our results on calvaria cells specifically during the mineralization phase of cultures are in keeping with these latter results, and with the view that ERK activation acts as a negative regulator of bone matrix mineralization. That ERK may have apparently opposite effects at different stages of osteogenesis is consistent with a model in which the temporal rate and concentration of growth factors are captured by the Ras and Rap1 systems and encoded into transient or sustained ERK activation, respectively, to deliver distinct biological outcomes (Sasagawa et al. 2005). Additional studies to understand the dynamics of ERK activation in different stages of osteogenesis are warranted (see also below).

The notion that ERK signaling has different effects at different stages of osteogenesis is paralleled by results with conditional inactivation of FGFR1 in osteogenic cells or in bones of transgenic mice that suggest a dual role for FGFR1 signaling at different stages of osteoblast maturation (Jacob et al. 2006). In osteo-chondroprogenitors or immature osteoblasts, FGFR1 deficiency increased proliferation and delayed differentiation and matrix mineralization, whereas in differentiated osteoblasts, FGFR1 deficiency enhanced mineralization. On the other hand, FGF2 was reported to induce apoptosis in murine differentiating calvaria osteoblasts and in the calvaria suture of mice overexpressing FGF2 through FGFR2 (Mansukhani et al. 2000). FGF2 also promoted proliferation in bone marrow stromal cells but inhibited alkaline phosphatase expression and matrix mineralization in mature osteoblasts via FGF23/FGFR/MAPK signaling (Xiao et al. 2013). Our data on sKL/FGF23-dependent ERK activation shows that activation is transient, which may explain why FGF23 but not FGF2 acts on mineralization rather than osteogenic cell proliferation and apoptosis (Mansukhani et al. 2000, Shalhoub et al. 2011, Xiao et al. 2013). It is also worth noting that PDZ-binding motif (TAZ) protein, the coactivator and repressor of the master transcription factors of osteogenesis (Runx2) and adipogenesis (PPAR $\gamma$ ), is negatively regulated by FGF2 via JNK signaling in mouse osteoblast MC3T3-E1 cells (Eda et al. 2008), while sKL/ FGF23-dependent hypomineralization requires the ERK pathway (Kyono et al. 2012). Fgf23 but not Fgf2 expression 
is markedly upregulated by $1,25 \mathrm{D}$ in osteoblasts/ osteocytes, in parallel with the expression of the vitamin D receptor (Yamamoto et al. 2010). Taken together with the dynamics of FGFRs during osteoblastogenesis (Wang et al. 2008, Su et al. 2014), specific cellular settings may provide the specific context in which sKL and FGF23 act on bone mineralization.

The expression of Phex, encoding a protein with homology to zinc metallopeptidases on the $\mathrm{X}$ chromosome, is mostly limited to osteoblasts/ osteocytes and odontoblasts (Ruchon et al. 2000). Lossof-function mutations in Phex cause hypophosphatemia and hypomineralization in bones and teeth, possibly through accumulation of phosphaturic factors (Feng et al. 2013). Like $k l / k l$ mice, Hyp mice show high levels of FGF23 (Nakatani et al. 2009). Little information is available on Klotho in XLH. Disruption of Klotho in Hyp mice (Klotho null-Hyp) indicates that Klotho is epistatic to PHEX in biochemical parameters and lifespan (Brownstein et al. 2010). Taken together with our data on the downregulation of Phex in bones of $\mathrm{kl} / \mathrm{kl}$ mice treated with $s K L$, we propose the interdependence of FGF23, Klotho (sKL) and PHEX in skeletal homeostasis. It is possible that sKL treatment of Hyp mice may impact bone mineralization, but detecting such mineralization changes may be difficult, given that the downstream effector of sKL-FGF23, i.e., Phex, is inactive in Hyp mice. Our data may connect two independent findings, that is, the 1,25D-dependent upregulation and downregulation of $F g f 23$ and Phex expression, respectively (Hines et al. 2004, Kolek et al. 2005, Barthel et al. 2007). On the other hand, sKL treatment does not alter the gene expression levels of $S p p 1, D m p 1$ and Mepe, which are higher in $k l / k l$ mouse bones compared by those in WT mice. This result indicates that hypomineralization of bones of $\mathrm{kl} / \mathrm{kl}$ mice treated with sKL appears not to be mediated by these genes.

In summary, treatment of $\mathrm{kl} / \mathrm{kl}$ mice with sKL does not rescue their osteopenia, but rather suppresses bone mineralization. sKL participates in FGF23 signaling in bones of $k l / k l$ mice, resulting in ERK1/2 activation and repression of PHEX, which is responsible at least in part for the intrinsic mineralization defects seen in $\mathrm{kl} / \mathrm{kl}$ bone (Fig. 7).

\section{Supplementary data}

This is linked to the online version of the paper at https://doi.org/10.1530/ JOE-17-0683.
Declaration of interest

The authors declare that there is no conflict of interest that could be perceived as prejudicing the impartiality of the research reported.

Funding

This work was supported in part by grants from the Ministry of Education, Science, Sports and Culture, Japan (18592001 and 20592139 to $Y$ Y and 21791788 to $T$ M), and the Canadian Institutes of Health Research (MOP 83704 to J E A).

\section{Acknowledgements}

The authors thank S Suzuki, S Kitabatake and Y Shibata for their technical assistance. They thank E Bonnelye, Laboratoire de Génomique Fonctionelle de Lyon, for the valuable discussions.

\section{References}

ADHR Consortium 2000 Autosomal dominant hypophosphataemic rickets is associated with mutations in FGF23. Nature Genetics 26 345-348. (https://doi.org/10.1038/81664)

Andrukhova O, Streicher C, Zeitz U \& Erben RG 2016 Fgf23 and parathyroid hormone signaling interact in kidney and bone. Molecular and Cellular Endocrinology 436 224-239. (https://doi.org/10.1016/j. mce.2016.07.035)

Andrukhova O, Bayer J, Schüler C, Zeitz U, Murali SK, Ada S, Alvarez-Pez JM, Smorodchenko A \& Erben RG 2017 Klotho lacks an FGF23-independent role in mineral homeostasis. Journal of Bone and Mineral Research 32 2049-2061. (https://doi.org/10.1002/ jbmr.3195)

Barthel TK, Mathern DR, Whitfield GK, Haussler CA, Hopper HA 4th, Hsieh JC, Slater SA, Hsieh G, Kaczmarska M \& Jurutka PW 2007 1,25-Dihydroxyvitamin $\mathrm{D}_{3}$ /VDR-mediated induction of FGF23 as well as transcriptional control of other bone anabolic and catabolic genes that orchestrate the regulation of phosphate and calcium mineral metabolism. Journal of Steroid Biochemistry and Molecular Biology 103 381-388. (https://doi.org/10.1016/j. jsbmb.2006.12.054)

Bellows CG, Sodek J, Yao KL \& Aubin JE 1986 Phenotypic differences in subclones and long-term cultures of clonally derived rat bone cell lines. Journal of Cellular Biochemistry 31 153-169. (https://doi. org/10.1002/jcb.240310207)

Ben-Dov IZ, Galitzer H, Lavi-Moshayoff V, Goetz R, Kuro-O M, Mohammadi M, Sirkis R, Naveh-Many T \& Silver J 2007 The parathyroid is a target organ for FGF23 in rats. Journal of Clinical Investigation 117 4003-4008.

Brownstein CA, Zhang J, Stillman A, Ellis B, Troiano N, Adams DJ, Gundberg CM, Lifton RP \& Carpenter TO 2010 Increased bone volume and correction of HYP mouse hypophosphatemia in the Klotho/HYP mouse. Endocrinology 151 492-501. (https://doi. org/10.1210/en.2009-0564)

Chang Q, Hoefs S, van der Kemp AW, Topala CN, Bindels RJ \& Hoenderop JG 2005 The $\beta$-glucuronidase klotho hydrolyzes and activates the TRPV5 channel. Science 310 490-493. (https://doi. org/10.1126/science.1114245)

Chen CD, Podvin S, Gillespie E, Leeman SE \& Abraham CR 2007 Insulin stimulates the cleavage and release of the extracellular domain of Klotho by ADAM10 and ADAM17. PNAS 104 19796-19801. (https:// doi.org/10.1073/pnas.0709805104) 
Chen TH, Kuro-O M, Chen CH, Sue YM, Chen YC, Wu HH \& Cheng CY 2013 The secreted Klotho protein restores phosphate retention and suppresses accelerated aging in Klotho mutant mice. European Journal of Pharmacology 698 67-73. (https://doi.org/10.1016/j. ejphar.2012.09.032)

Choi YJ, Jeong S, Yoon KA, Sung HJ, Cho HS, Kim DW \& Cho JY 2017Deficiency of DGCR8 increases bone formation through downregulation of miR-22 expression.Bone 103 287-294. (https://doi org/ 10.1016/j.bone.2017.07.021)

Eda H, Aoki K, Marumo K, Fujii K \& Ohkawa K 2008 FGF-2 signaling induces downregulation of TAZ protein in osteoblastic MC3T3-E1 cells. Biochemical and Biophysical Research Communications 366 471-475. (https://doi.org/10.1016/j.bbrc.2007.11.140)

Faul C, Amaral AP, Oskouei B, Hu MC, Sloan A, Isakova T, Gutiérrez OM, Aguillon-Prada R, Lincoln J, Hare JM, et al. 2011 FGF23 induces left ventricular hypertrophy. Journal of Clinical Investigation 121 4393-4408. (https://doi.org/10.1172/JCI46122)

Feng JQ, Clinkenbeard EL, Yuan B, White KE \& Drezner MK 2013 Osteocyte regulation of phosphate homeostasis and bone mineralization underlies the pathophysiology of the heritable disorders of rickets and osteomalacia. Bone 54 213-221. (https://doi. org/10.1016/j.bone.2013.01.046)

Frishberg Y, Ito N, Rinat C, Yamazaki Y, Feinstein S, Urakawa I, Navon-Elkan P, Becker-Cohen R, Yamashita T, Araya K, et al. 2007 Hyperostosis-hyperphosphatemia syndrome: a congenital disorder of O-glycosylation associated with augmented processing of fibroblast growth factor 23. Journal of Bone and Mineral Research 22 235-242. (https://doi.org/10.1359/jbmr.061105)

Ge C, Xiao G, Jiang D \& Franceschi RT 2007 Critical role of the extracellular signal-regulated kinase-MAPK pathway in osteoblast differentiation and skeletal development. Journal of Cell Biology 176 709-718. (https://doi.org/10.1083/jcb.200610046)

Goetz R, Nakada Y, Hu MC, Kurosu H, Wang L, Nakatani T, Shi M, Eliseenkova AV, Razzaque MS, Moe OW, et al. 2010 Isolated C-terminal tail of FGF23 alleviates hypophosphatemia by inhibiting FGF23-FGFR-Klotho complex formation. PNAS 107 407-412. (https:// doi.org/10.1073/pnas.0902006107)

Guo R \& Quarles LD 1997 Cloning and sequencing of human PEX from a bone cDNA library: evidence for its developmental stage-specific regulation in osteoblasts. Journal of Bone and Mineral Research 12 1009-1017. (https://doi.org/10.1359/jbmr.1997.12.7.1009)

Hines ER, Kolek OI, Jones MD, Serey SH, Sirjani NB, Kiela PR, Jurutka PW, Haussler MR, Collins JF \& Ghishan FK 2004 1,25-dihydroxyvitamin $\mathrm{D}_{3}$ down-regulation of PHEX gene expression is mediated by apparent repression of a $110 \mathrm{kDa}$ transfactor that binds to a polyadenine element in the promoter. Journal of Biological Chemistry 279 46406-46414. (https://doi.org/10.1074/jbc.M404278200)

Ichikawa S, Imel EA, Kreiter ML, Yu X, Mackenzie DS, Sorenson AH, Goetz R, Mohammadi M, White KE \& Econs MJ 2007 A homozygous missense mutation in human KLOTHO causes severe tumoral calcinosis. Journal of Clinical Investigation 117 2684-2691. (https://doi. org/10.1172/JCI31330)

Jacob AL, Smith C, Partanen J \& Ornitz DM 2006 Fibroblast growth factor receptor 1 signaling in the osteo-chondrogenic cell lineage regulates sequential steps of osteoblast maturation. Developmental Biology 296 315-328. (https://doi.org/10.1016/j.ydbio.2006.05.031)

Kato K, Jeanneau C, Tarp MA, Benet-Pagès A, Lorenz-Depiereux B, Bennett EP, Mandel U, Strom TM \& Clausen H 2006 Polypeptide GalNAc-transferase T3 and familial tumoral calcinosis. Secretion of fibroblast growth factor 23 requires O-glycosylation. Journal of Biological Chemistry 281 18370-18377. (https://doi.org/10.1074/jbc. M602469200)

Kawaguchi H, Manabe N, Miyaura C, Chikuda H, Nakamura K \& Kuro-O M 1999 Independent impairment of osteoblast and osteoclast differentiation in klotho mouse exhibiting low-turnover osteopenia. Journal of Clinical Investigation 1104 229-237. (https://doi. org/10.1172/JCI5705)

Kawai M, Kinoshita S, Kimoto A, Hasegawa Y, Miyagawa K, Yamazaki M, Ohata Y, Ozono K \& Michigami T 2013 FGF23 suppresses chondrocyte proliferation in the presence of soluble $\alpha$-Klotho both in vitro and in vivo. Journal of Biological Chemistry 288 2414-2427. (https://doi.org/10.1074/jbc.M112.410043)

Kawai M, Kinoshita S, Shimba S, Ozono K \& Michigami T 2014 Sympathetic activation induces skeletal $F g f 23$ expression in a circadian rhythm-dependent manner. Journal of Biological Chemistry 289 1457-1466. (https://doi.org/10.1074/jbc.M113.500850)

Kawano K, Ogata N, Chiano M, Molloy H, Kleyn P, Spector TD, Uchida M, Hosoi T, Suzuki T, Orimo H, et al. 2002 Klotho gene polymorphisms associated with bone density of aged postmenopausal women. Journal of Bone and Mineral Research 17 1744-1751. (https:// doi.org/10.1359/jbmr.2002.17.10.1744)

Kolek OI, Hines ER, Jones MD, LeSueur LK, Lipko MA, Kiela PR, Collins JF, Haussler MR \& Ghishan FK 2005 1 $\alpha, 25$ Dihydroxyvitamin $\mathrm{D}_{3}$ upregulates FGF23 gene expression in bone: the final link in a renal-gastrointestinal-skeletal axis that controls phosphate transport. American Journal of Physiology: Gastrointestinal and Liver Physiology 289 G1036-G1042. (https://doi.org/10.1152/ ajpgi.00243.2005)

Komaba H, Kaludjerovic J, Hu DZ, Nagano K, Amano K, Ide N, Sato T, Densmore MJ, Hanai JI, Olauson H, et al. 2017 Klotho expression in osteocytes regulates bone metabolism and controls bone formation. Kidney International 92 599-611. (https://doi.org/10.1016/j. kint.2017.02.014)

Kono SJ, Oshima Y, Hoshi K, Bonewald LF, Oda H, Nakamura K, Kawaguchi H \& Tanaka S 2007 Erk pathways negatively regulate matrix mineralization. Bone 40 68-74. (https://doi.org/10.1016/j. bone.2006.07.024)

Kuro-O M, Matsumura Y, Aizawa H, Kawaguchi H, Suga T, Utsugi T, Ohyama Y, Kurabayashi M, Kaname T, Kume E, et al. 1997 Mutation of the mouse klotho gene leads to a syndrome resembling ageing. Nature 390 45-51. (https://doi.org/10.1038/36285)

Kurosu H, Yamamoto M, Clark JD, Pastor JV, Nandi A, Gurnani P, McGuinness OP, Chikuda H, Yamaguchi M, Kawaguchi H, et al. 2005 Suppression of aging in mice by the hormone Klotho. Science 309 1829-1833. (https://doi.org/10.1126/science.1112766)

Kurosu H, Ogawa Y, Miyoshi M, Yamamoto M, Nandi A, Rosenblatt KP, Baum MG, Schiavi S, Hu MC, Moe OW, et al. 2006 Regulation of fibroblast growth factor-23 signaling by klotho. Journal of Biological Chemistry 281 6120-6123. (https://doi.org/10.1074/jbc. C500457200)

Kusaba T, Okigaki M, Matui A, Murakami M, Ishikawa K, Kimura T, Sonomura K, Adachi Y, Shibuya M, Shirayama T, et al. 2010 Klotho is associated with VEGF receptor-2 and the transient receptor potential canonical-1 $\mathrm{Ca}^{2+}$ channel to maintain endothelial integrity. PNAS 107 19308-19313. (https://doi.org/10.1073/ pnas.1008544107)

Kyono A, Avishai N, Ouyang Z, Landreth GE \& Murakami S 2012 FGF and ERK signaling coordinately regulate mineralization-related genes and play essential roles in osteocyte differentiation. Journal of Bone and Mineral Metabolism 30 19-30. (https://doi.org/10.1007/s00774011-0288-2)

Larsson T, Marsell R, Schipani E, Ohlsson C, Ljunggren O, Tenenhouse HS, Jüppner H \& Jonsson KB 2004 Transgenic mice expressing fibroblast growth factor 23 under the control of the $\alpha 1$ (I) collagen promoter exhibit growth retardation, osteomalacia, and disturbed phosphate homeostasis. Endocrinology 145 3087-3094. (https://doi.org/10.1210/en.2003-1768)

Lindberg K, Amin R, Moe OW, Hu MC, Erben RG, Östman Wernerson A, Lanske B, Olauson H \& Larsson TE 2014 The kidney is the principal organ mediating klotho effects. Journal of the American
() 2018 Society for Endocrinology Published by Bioscientifica Ltd. Printed in Great Britain 
Society of Nephrology 25 2169-2175. (https://doi.org/10.1681/ ASN.2013111209)

Liu H, Fergusson MM, Castilho RM, Liu J, Cao L, Chen J, Malide D, Rovira II, Schimel D, Kuo CJ, et al. 2007 Augmented Wnt signaling in a mammalian model of accelerated aging. Science 317 803-806. (https://doi.org/10.1126/science.1143578)

Mansukhani A, Bellosta P, Sahni M \& Basilico C 2000 Signaling by fibroblast growth factors $(F g f)$ and fibroblast growth factor receptor 2 ( $F g f r 2$ )-activating mutations blocks mineralization and induces apoptosis in osteoblasts. Journal of Cell Biology 149 1297-1308. (https://doi.org/10.1083/jcb.149.6.1297)

Matsumura Y, Aizawa H, Shiraki-Iida T, Nagai R, Kuro-O M \& Nabeshima Y 1998 Identification of the human klotho gene and its two transcripts encoding membrane and secreted klotho protein. Biochemical and Biophysical Research Communications 242 626-630. (https://doi.org/10.1006/bbrc.1997.8019)

Miao D, Bai X, Panda D, McKee M, Karaplis A \& Goltzman D 2001 Osteomalacia in hyp mice is associated with abnormal phex expression and with altered bone matrix protein expression and deposition. Endocrinology 142 926-939. (https://doi.org/10.1210/ endo.142.2.7976)

Minamizaki T, Yoshiko Y, Kozai K, Aubin JE \& Maeda N 2009 EP2 and EP4 receptors differentially mediate MAPK pathways underlying anabolic actions of prostaglandin $\mathrm{E}_{2}$ on bone formation in rat calvaria cell cultures. Bone $\mathbf{4 4} 1177-1185$. (https://doi.org/10.1016/j. bone.2009.02.010)

Murali SK, Andrukhova O, Clinkenbeard EL, White KE \& Erben RG 2016 Excessive osteocytic Fgf23 secretion contributes to pyrophosphate accumulation and mineralization xefect in Hyp mice. PLoS Biology 14 e1002427. (https://doi.org/10.1371/journal.pbio.1002427)

Nakatani T, Ohnishi M \& Razzaque MS 2009 Inactivation of klotho function induces hyperphosphatemia even in presence of high serum fibroblast growth factor 23 levels in a genetically engineered hypophosphatemic (Hyp) mouse model. FASEB Journal 23 3702-3711. (https://doi.org/10.1096/fj.08-123992)

Pedersen L, Pedersen SM, Brasen CL \& Rasmussen LM 2013 Soluble serum Klotho levels in healthy subjects. Comparison of two different immunoassays. Clinical Biochemistry 46 1079-1083. (https://doi. org/10.1016/j.clinbiochem.2013.05.046)

Rhee Y, Bivi N, Farrow E, Lezcano V, Plotkin LI, White KE \& Bellido T 2011 Parathyroid hormone receptor signaling in osteocytes increases the expression of fibroblast growth factor-23 in vitro and in vivo. Bone 49 636-643. (https://doi.org/10.1016/j.bone.2011.06.025)

Riminucci M, Collins MT, Fedarko NS, Cherman N, Corsi A, White KE, Waguespack S, Gupta A, Hannon T, Econs MJ, et al. 2003 FGF-23 in fibrous dysplasia of bone and its relationship to renal phosphate wasting. Journal of Clinical Investigation 112 683-692. (https://doi. org/10.1172/JCI18399)

Ruchon AF, Tenenhouse HS, Marcinkiewicz M, Siegfried G, Aubin JE, DesGroseillers L, Crine P \& Boileau G 2000 Developmental expression and tissue distribution of Phex protein: effect of the Hyp mutation and relationship to bone markers. Journal of Bone and Mineral Research 15 1440-1450. (https://doi.org/10.1359/jbmr.2000.15.8.1440)

Sasagawa S, Ozaki Y, Fujita K \& Kuroda S 2005 Prediction and validation of the distinct dynamics of transient and sustained ERK activation. Nature Cell Biology 7 365-373. (https://doi.org/10.1038/ncb1233)

Segawa H, Yamanaka S, Ohno Y, Onitsuka A, Shiozawa K, Aranami F, Furutani J, Tomoe Y, Ito M, Kuwahata M, et al. 2007 Correlation between hyperphosphatemia and type II Na-P cotransporter activity in klotho mice. American Journal of Physiology: Renal Physiology 292 F769-F779. (https://doi.org/10.1152/ajprenal.00248.2006)

Shalhoub V, Ward SC, Sun B, Stevens J, Renshaw L, Hawkins N \& Richards WG 2011 Fibroblast growth factor 23 (FGF23) and $\alpha$-klotho stimulate osteoblastic MC3T3.E1 cell proliferation and inhibit mineralization. Calcified Tissue International 89 140-150. (https://doi. org/10.1007/s00223-011-9501-5)
Shimada T, Hasegawa H, Yamazaki Y, Muto T, Hino R, Takeuchi Y, Fujita T, Nakahara K, Fukumoto S \& Yamashita T 2004a FGF-23 is a potent regulator of vitamin D metabolism and phosphate homeostasis. Journal of Bone and Mineral Research 19 429-435. (https://doi. org/10.1359/JBMR.0301264)

Shimada T, Kakitani M, Yamazaki Y, Hasegawa H, Takeuchi Y, Fujita T, Fukumoto S, Tomizuka K \& Yamashita T 2004b Targeted ablation of $F g f 23$ demonstrates an essential physiological role of FGF23 in phosphate and vitamin D metabolism. Journal of Clinical Investigation 113 561-568. (https://doi.org/10.1172/JCI200419081)

Shimoyama Y, Nishio K, Hamajima N \& Niwa T 2009 KLOTHO gene polymorphisms G-395A and C1818T are associated with lipid and glucose metabolism, bone mineral density and systolic blood pressure in Japanese healthy subjects. Clinica Chimica Acta 406 134-138. (https://doi.org/10.1016/j.cca.2009.06.011)

Smith RC, O'Bryan LM, Farrow EG, Summers LJ, Clinkenbeard EL, Roberts JL, Cass TA, Saha J, Broderick C, Ma YL, et al. 2012 Circulating aKlotho influences phosphate handling by controlling FGF23 production. Journal of Clinical Investigation 122 4710-4715. (https:// doi.org/10.1172/JCI64986)

Su N, Jin M \& Chen L 2014 Role of FGF/FGFR signaling in skeletal development and homeostasis: learning from mouse models. Bone Research 2 14003. (https://doi.org/10.1038/boneres.2014.3)

Suzuki H, Amizuka N, Oda K, Noda M, Ohshima H \& Maeda T 2008 Histological and elemental analysis of impaired bone mineralization in klotho-deficient mice. Journal of Anatomy 212 275-285. (https:// doi.org/10.1111/j.1469-7580.2008.00859.x)

Tagliabracci VS, Engel JL, Wiley SE, Xiao J, Gonzalez DJ, Nidumanda Appaiah H, Koller A, Nizet V, White KE, et al. 2014 Dynamic regulation of FGF23 by Fam20C phosphorylation, GalNAc-T3 glycosylation, and furin proteolysis. PNAS 111 5520-5525. (https:// doi.org/10.1073/pnas.1402218111)

Urakawa I, Yamazaki Y, Shimada T, Iijima K, Hasegawa H, Okawa K, Fujita T, Fukumoto S \& Yamashita T 2006 Klotho converts canonical FGF receptor into a specific receptor for FGF23. Nature 444 770-774. (https://doi.org/10.1038/nature05315)

Wang Y \& Sun Z 2009 Current understanding of klotho. Ageing Research Reviews 8 43-51. (https://doi.org/10.1016/j.arr.2008.10.002)

Wang H, Yoshiko Y, Yamamoto R, Minamizaki T, Kozai K, Tanne K, Aubin JE \& Maeda N 2008 Overexpression of fibroblast growth factor 23 suppresses osteoblast differentiation and matrix mineralization in vitro. Journal of Bone and Mineral Research 23 939-948. (https://doi. org/10.1359/jbmr.080220)

Wolf MT, An SW, Nie M, Bal MS \& Huang CL 2014 Klotho up-regulates renal calcium channel transient receptor potential vanilloid 5 (TRPV5) by intra- and extracellular N-glycosylation-dependent mechanisms. Journal of Biological Chemistry 289 35849-35857. (https://doi.org/10.1074/jbc.M114.616649)

Xiao L, Esliger A \& Hurley MM 2013 Nuclear fibroblast growth factor 2 (FGF2) isoforms inhibit bone marrow stromal cell mineralization through FGF23/FGFR/MAPK in vitro. Journal of Bone and Mineral Research 28 35-45. (https://doi.org/10.1002/jbmr.1721)

$\mathrm{Xu}$ Y \& Sun Z 2015 Molecular basis of klotho: from gene to function in aging. Endocrine Reviews 36 174-193. (https://doi.org/10.1210/ er.2013-1079)

Yamamoto R, Minamizaki T, Yoshiko Y, Yoshioka H, Tanne K, Aubin JE \& Maeda $\mathrm{N} 20101 \alpha, 25$-dihydroxyvitamin $\mathrm{D}_{3}$ acts predominately in mature osteoblasts under conditions of high extracellular phosphate to increase fibroblast growth factor 23 production in vitro. Journal of Endocrinology 206 279-286. (https://doi. org/10.1677/JOE-10-0058)

Yoshida T, Fujimori T \& Nabeshima Y 2002 Mediation of unusually high concentrations of 1,25-dihydroxyvitamin D in homozygous klotho mutant mice by increased expression of renal $1 \alpha$-hydroxylase gene. Endocrinology 143 683-689. (https://doi.org/10.1210/ endo.143.2.8657) 
Yoshiko Y, Wang H, Minamizaki T, Ijuin C, Yamamoto R, Suemune S, Kozai K, Tanne K, Aubin JE \& Maeda N 2007b Mineralized tissue cells are a principal source of FGF23. Bone $\mathbf{4 0}$ 1565-1573. (https://doi. org/10.1016/j.bone.2007.01.017)

autonomous Pi regulation via Pit1 plays a role in bone mineralization. Molecular and Cellular Biology 27 4465-4474. (https://doi.org/10.1128/ MCB.00104-07)

Received in final form 3 April 2018

Accepted 9 April 2018

Accepted Preprint published online 9 April 2018 